\title{
A spatially explicit reconstruction of forest cover in China over $1700-2000$
}

\author{
Fanneng $\mathrm{He}^{\mathrm{a}}$, Shicheng $\mathrm{Li}^{\mathrm{a}, \mathrm{b}, *}$, Xuezhen Zhang ${ }^{\mathrm{a}}$ \\ ${ }^{a}$ Key Laboratory of Land Surface Pattern and Simulation, Institute of Geographical Sciences and Natural Resources Research, Chinese Academy of Sciences, Beijing 100101, China \\ ${ }^{\mathrm{b}}$ University of Chinese Academy of Sciences, No.19A Yuquan Road, Beijing 100049, China
}

\section{A R T I C L E I N F O}

\section{Article history:}

Received 21 June 2014

Received in revised form 1 May 2015

Accepted 8 May 2015

Available online 16 May 2015

\section{Keywords:}

Forest cover

Spatially explicit

Reconstruction

China

Past 300 years

Land suitability for cultivation

\begin{abstract}
A B S T R A C T
The spatially explicit reconstruction of historical forest plays an important role in understanding human modifications of land surfaces and its environmental effects. Based on an analysis of the forest change history of China, we devised a reconstruction method for the historical forest cover in China. The core idea of the method is that the lands with high suitability for cultivation will be cultivated and deforested first, spreading to marginal lands with lower suitability for cultivation. By determining the possible maximum distribution extent of the forest, as well as devising the land suitability for cultivation assessment model and provincial forest area allocation model, we created $10 \mathrm{~km}$ forest cover maps of China for the years 1700 to 2000 with 10 year intervals. By comparison with satellite-based data in 2000 , we found that the grids within $25 \%$ differences account for as much as $66.07 \%$ of all grids. The comparison with the historical documents-based data in northeast China indicated that the number of counties within $30 \%$ relative differences is 99 , accounting for $74.44 \%$ of all counties. Therefore, the forest area allocation model we devised can accurately reproduce the spatial patterns of historical forest cover in China. Our reconstruction indicates that from 1700 to the 1960 s, the deforestation mainly occurred in southwest China, the hilly regions of south China, the southeast of Gansu province, and northeast China; from the 1960 s to 2000 , the reforestation occurred in most traditional forested regions of China, particularly in the Tibet Plateau, hilly regions of south China and the Greater Khingan Mountains. The spatially explicit forest cover data sets we reconstructed can be used in global or regional climatic models to study the impact of land cover change on climate change.
\end{abstract}

(C) 2015 Elsevier B.V. All rights reserved.

\section{Introduction}

Human activities have significantly modified the land surface (Vitousek et al., 1997; Ellis et al., 2013). It is estimated that from 1700 to 2000 , approximately $42 \%$ to $68 \%$ of the land surface was impacted by land-use activities, including crops, pastures and wood harvesting (Hurtt et al., 2006). Such large-scale changes in land surface may have regional and global climatic and ecological implications (Feddema et al., 2005; Bala et al., 2007; Jetz et al., 2007; Pitman et al., 2011; Sterling et al., 2013) in biogeochemical (emissions of greenhouse gases and aerosols) and biogeophysical (albedo, evapotranspiration and surface roughness) manners (Bounoua et al., 2002; Bathiany et al., 2010; Pongratz et al., 2010).

In recent years, global or regional climate models have been widely used to assess the impacts of land use and land cover change on climate (Ellis et al., 2013; He et al., 2014), and spatially and temporally explicit land cover data sets and land cover transformation data sets spanning

\footnotetext{
* Corresponding author at: Room 3517,11A, Datun Road, Chaoyang District, Beijing 100101, China. Tel.: + 8610 64888203; fax: + 861064854230 .

E-mail addresses: hefn@igsnrr.ac.cn (F. He), lisc.10s@igsnrr.ac.cn (S. Li), xzzhang@igsnrr.ac.cn (X. Zhang).
}

several hundred years were required. Satellite-based data can provide a consistent map of land cover, but these data are only available for the past several decades (Houghton et al., 2012). Thus, many studies have devoted attention to the reconstruction of spatially explicit land cover data sets spanning a long time scale (Ellis et al., 2013; Miao et al., 2013; Yang et al., 2014, 2015; Fuchs et al., 2015).

For example, using satellite-based data and census data, the Center for Sustainability and the Global Environment (SAGE) has created a global cropland data set for $1700-1992$ with $0.5^{\circ}$ resolution using a 'hindcast modeling' technique (Ramankutty and Foley, 1999). Subsequently, Pongratz et al. (2008) expanded the time period to the last millennium based on global population data, SAGE data set and an assumption that the spatial patterns of crop and pasture areas are constant from $800 \mathrm{AD}$ to $1700 \mathrm{AD}$. In addition, based on the assumption that the current patterns of land cover mimic their historical distributions, Liu and Tian (2010) recreated the cropland, forest and urban covers of China for 1700-2005. By merging satellite imagery with census data, Leite et al. (2012) reconstructed a 5 arc minutes resolution yearly data set of land use for cropland, natural pastureland and planted pastureland of Brazil for 1940-1995. On the basis of high-resolution remote sensing data sets and historical archives at district and state levels, Tian et al. (2014) created the LULC data sets (including cropland, forest, 
grassland/shrubland, wasteland, and built up or settlement areas) at 5 arc minutes resolution during 1880-2010 in India. Using HIstoric Land Dynamics Assessment approach, Fuchs et al. (2013) reconstructed historical land change for Europe at $1 \mathrm{~km}$ resolution for 1950-2010 and a further extrapolation was made back to 1900 to assess the long-term impacts (Fuchs et al., 2015).

However, these studies paid most attention to cropland and pastureland, whereas the reconstruction of historical forest cover was hardly touched upon. And there are no reliable spatially explicit forest cover data sets of China. In the process of creating the cropland, forest and urban covers of China for 1700-2005, Liu and Tian (2010) made an assumption that the spatial patterns of historical land use are similar with contemporary spatial patterns of land use, which may be problematic (Houghton and Hackler, 2003).

Using a different method with the SAGE data set, Klein Goldewijk (2001) created the History Database of the Global Environment (HYDE). The latest HYDE 3.1 data set has a 5 arc minutes spatial resolution and spans a long time back to 12000 years ago (Klein Goldewijk et al., 2011), and it was created based on a satellite-based cropland map of the year 2000 and six major factors or assumptions. This data set has been used widely, but only cropland, pastureland and built-up areas are available. In addition, based on a non-linear relationship between population density and land use, Kaplan et al. (2009) estimated the deforestation of Europe for the period of 1000 BC-1850 AD. They later expanded the geographic scope to global and the time period to 8000 years ago (Kaplan et al., 2011). However, the forest area they used was estimated based on historical population and a relationship between population density and land use, and not derived from the essential historical records.

Moreover, because of the absence of historical maps, most of them did not validate their data sets in effective ways, which will bring ambiguous uncertainties to the users of these data sets. Some assessments also indicated that the global data sets hardly captured the necessary detail at local-regional scales (He et al., 2013; Klein Goldewijk and Verburg, 2013; Zhang et al., 2013).

As a result, in this study, based on the understanding of history of forest change in China, we tried to recreate the spatially explicit forest cover data set of China for the years ranging from 1700 to 2000, overcoming several limitations of previous studies.

\section{Materials and methods}

The study area is the current territory of mainland China (Fig. 1). The territory and provincial units of China have changed over the past 300 years. Because historical inventory data were available for the province distribution in the 1820 s, so we used the provincial units in the 1820 s, as did Ge et al. (2004). The current provinces were therefore regrouped into those from the 1820s (Tan, 1991) by merging Beijing, Tianjin and Hebei into Jing-Jin-Ji, Shanghai and Jiangsu into Hu-Ning, Chongqing and Sichuan into Chuan-Yu, Hainan and Guangdong into Yue-Qiong, and Ningxia and Gansu into Gan-Ning.

\subsection{Provincial forest area data}

The provincial forest area was derived from He et al. (2008), Ye and Fang (2011), and the State Forestry Administration of China (SFAC). Using historical documents, modern survey and inventory data, and the existing study results, He et al. (2008) estimated the provincial forest area with 50 year intervals for 1700-1949. This is the latest quantitative provincial forest area data, covering a long time scale and the entire mainland China. Ye and Fang (2011) estimated the county level forest coverage of northeast China (the provinces numbered 1-3 in Fig. 1) for 1683-1950 based on historical archives and potential natural vegetation. Because of its higher spatial resolution and more reliable data sources than He et al. (2008), the estimations of Ye and Fang (2011) for the 3 provinces were used in this study.
The SFAC provided the provincial forest area for 1950-1962, 19731976, 1977-1981, 1984-1988, 1989-1993, 1994-1998 and 1999-2003 (SFAC, 1965, 1977, 1982, 1989, 1994, 1999, 2004). For 1950-1962, the data were dominantly derived from field investigations. Although some studies noted that the SFAC data for 1950-1962 may underestimate the forest area because the field investigation did not cover the entire territory of China (Qin, 2005), it still captured the main status of the forest resources of the entire country at that time (Ge et al., 2008). For the early 1970s and onward, the forest areas were based on the Forest Resource Inventory of China. These inventories were compiled from more than 250,000 plots (160,000 permanent sample plots plus 90,000 temporary sample plots) across the country.

The provincial forest area data of He et al. (2008) for 1700-1949 and the county level forest area data of Ye and Fang (2011) for 1683-1950 were calibrated according to contemporary forest inventory data. Therefore, they can link together with contemporary forest inventory data directly. Moreover, the county level data of Ye and Fang (2011) was aggregated to the provincial level. And based on the change tendency of the provincial forest area, interpolation with decadal interval was performed for the period from 1700 to 2000 for each province. Eventually, we obtained the provincial forest area data set of China for 1700-2000.

In addition to forest, during the reconstruction process, the provincial cropland area data set of China for 1700-2000 was also used to reproduce the crop cover of China over the past three centuries. The data sources are illustrated in Table 1.

\subsection{Methodology}

It is reported that China had been extensively covered by forests with the forest coverage of $49.6 \%-64 \%$ in the pre-agricultural period (Ling, 1983; Ma et al., 1997; Fan and Dong, 2001). As the society developed and the population increased, the forest area decreased dramatically, especially over the past several centuries. The main driving force of deforestation is human land use activities, especially land reclamation (Wu, 1996). During the land reclamation process, the lands with good natural conditions, i.e., flat, low altitude, close to rivers, suitable radiation and temperature and easy to reach, will be cultivated first, gradually followed by marginal lands with harsh natural environments (Han, 2012). That is to say, the lands with high suitability for cultivation will be deforested first, followed by marginal lands with lower suitability for cultivation. Based on this principle, we devised the reconstruction method of historical forest cover (Fig. 2).

To create a spatially explicit forest cover data set of China, the possible maximum distribution extent of forest (hereafter, MDEF) in the absence of human activities was created to constrain the allocation extent of forest (Section 2.2.1). Within the MDEF, the Land Suitability for Cultivation (LSC) was assessed to determine the lands with priority to cultivate and deforest (Section 2.2.2). According to the LSC as spatial weight, the crop cover was obtained and subtracted from the MDEF (Section 2.2.3). Within the remaining forest distribution extent, the provincial forest area allocation model was created based on the reciprocal of LSC (Section 2.2.4). Inputting the provincial forest area data set into this allocation model, the forest cover maps of China with $10 \mathrm{~km}$ resolution for 1700-2000 were reconstructed.

\subsubsection{The possible maximum distribution extent of forest in the absence of human activities \\ Potential natural vegetation is widely used to study historical chang- es of land cover caused by human activities (Ramankutty and Foley, 1999; Pongratz et al., 2008). The 5 arc minutes global potential vegeta- tion developed by Ramankutty and Foley (1999; hereafter, RF99) is widely used. However, it is meant to be used only for continental- global scale, and some uncertainties exist in regional scales (Zhang et al., 2011; Levavasseur et al., 2013). Because of the unavailability of a}




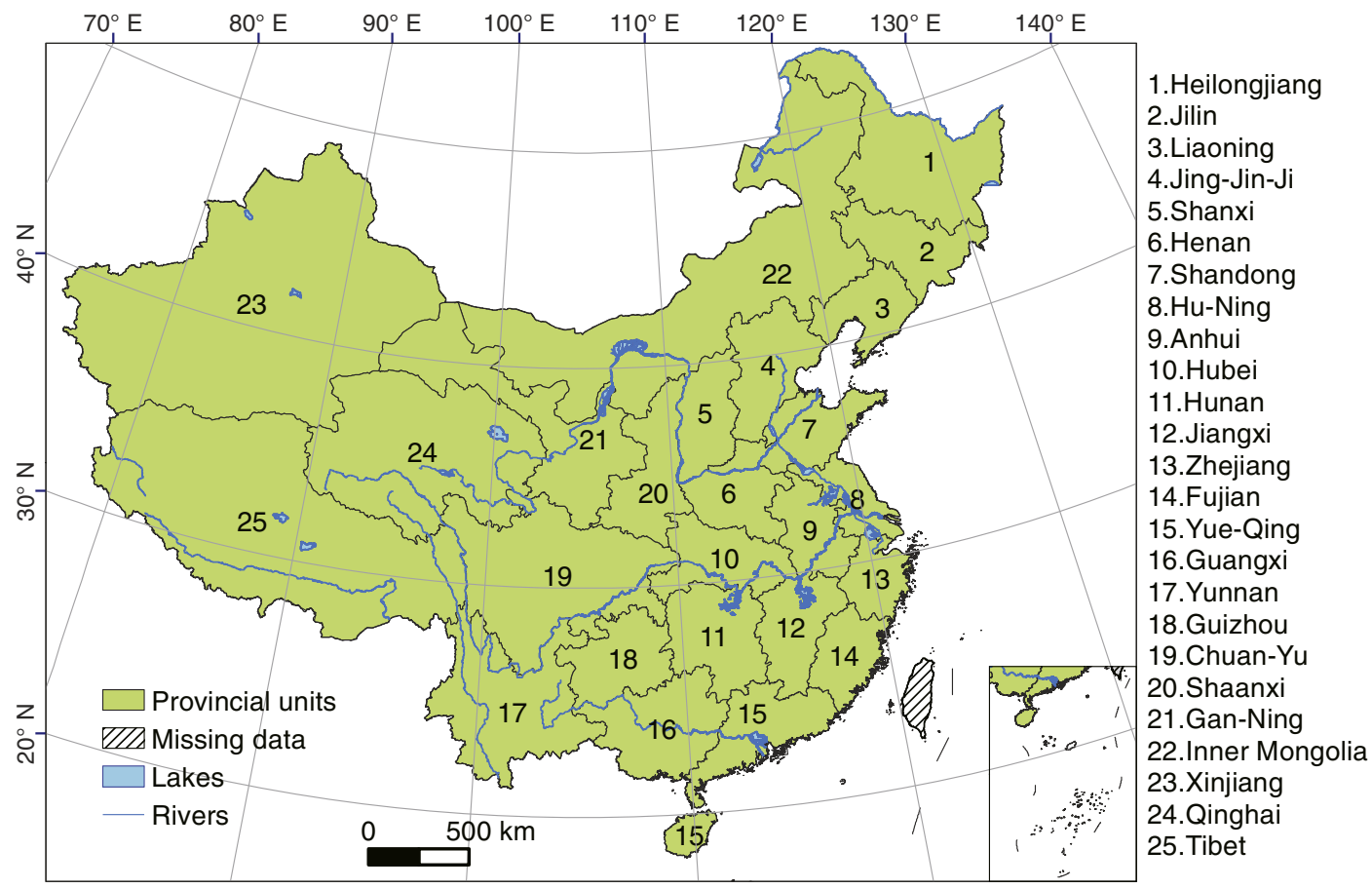

Fig. 1. Location of the study area.

reliable potential vegetation of China, the MDEF was devised in this study to constrain the allocation extent of forest.

It is quite acceptable that the contemporary forest regions observed by satellite sensors were also forest regions in history because there were scarce human activities. In terms of the contemporary non-forest regions (e.g., traditional cultivated regions, built-up regions, etc.) observed by satellite sensors, it is likely that the forest also existed in these regions in the past, including the North China Plain, the Sichuan Basin of China, etc. Based on the above analysis, we made an assumption that the contemporary forest regions observed by satellite sensors were also forest regions in history and that the contemporary non-forest regions observed by satellite sensors were possibly also forest regions in history, but their distribution scopes did not exceed the forest regions reflected in potential vegetation. In this study, RF99 was used to reflect the forest regions dominated by land use.

As a result, we overlaid the several available satellite-based forest cover maps of China and flagged all the grid cells with $>0 \%$ forest coverage, and all the flagged grid cells were then classified as contemporary forest regions. Then, the cultivated regions and built-up regions observed by satellite sensors in the contemporary non-forest regions were replaced by RF99 to identify historical forest distribution regions in contemporary non-forest regions. Finally, the contemporary forest regions and the identified historical forest distribution regions were combined to obtain the MDEF (Fig. 3). Moreover, alpine timberline (Wang et al., 2004) was used to control the extent of forest distribution in some provincial units of west China (Table 2 ).

The satellite-based data set we used is National Land-use/Land cover data set (hereafter, NLCD; available at: http://www.geodata.cn) for three time periods: the end of the 1980s, 1995/1996, and 2000 (Liu et al., 2005, 2014), which was validated against field survey. This $1 \mathrm{~km}$ data set was up-scaled to $10 \mathrm{~km}$, and the 5 arc minutes RF99 data were projected and also resampled to $10 \mathrm{~km}$ during the process.

The area of MDEF accounts for 55.4\% of the total land area of China, which is close to the forest coverage estimations of previous studies (e.g., Ma et al., 1997).

\subsubsection{Land suitability for the cultivation assessment model}

The LSC was assessed in this work to transform the provincial forest area for 1700-2000 into spatially explicit forest cover maps. Generally speaking, the LSC is jointly determined by topography, climate conditions, rivers and soil. For China, irrigation has been advanced even in archaic periods, especially in the traditional cultivated regions of China (Wu, 1996), so the distance from rivers plays only a slight role on LSC. At the $10 \mathrm{~km}$ grid level, soil mainly determines whether the land is suitable for cultivation, and its effects on reclamation are incorporated in the present cropland scope (Sun and Shi, 2003). Therefore, in this

Table 1

Sources of forest and cropland area data of mainland China from 1700 to 2000 .

\begin{tabular}{|c|c|c|c|c|}
\hline Data & Region & Time slices covered & Spatial resolution & Data sources \\
\hline \multirow[t]{3}{*}{ Forest } & 22 provincial units of China & $1700,1750,1800,1850,1900,1949$ & Provincial & He et al. (2008) \\
\hline & 3 provincial units of northeast China & $1683,1780,1950$ & County & Ye and Fang (2011) \\
\hline & 25 provincial units of China & $\begin{array}{l}\text { 1950-1962, 1973-1976, 1977-1981, 1984-1988, } \\
\text { 1989-1993, 1994-1998, 1999-2003 }\end{array}$ & Provincial & $\begin{array}{l}\text { SFAC }(1965,1977,1982,1989, \\
1994,1999,2004)\end{array}$ \\
\hline \multirow[t]{6}{*}{ Cropland } & $\begin{array}{l}18 \text { provincial units in traditional } \\
\text { cultivated region }\end{array}$ & $\begin{array}{l}\text { 1661, 1685, 1724, 1784, 1820, 1873, 1887, 1893, } \\
1913,1933\end{array}$ & Provincial & Ge et al. (2004) \\
\hline & 3 provincial units of northeast China & $1683,1735,1780,1908,1914,1931,1940$ & County & Ye et al. (2009) \\
\hline & 4 frontier provincial units & 1953 & Provincial & NBSC (1953) \\
\hline & 25 provincial units of China & 1949-1960, 1996-2000 & Provincial & NBSC (1950-1961, 1997-2001) \\
\hline & 25 provincial units of China & 1961-1985 & National & Feng et al. (2005) \\
\hline & 25 provincial units of China & 1986-1996 & Provincial & MLR (1987-1997) \\
\hline
\end{tabular}




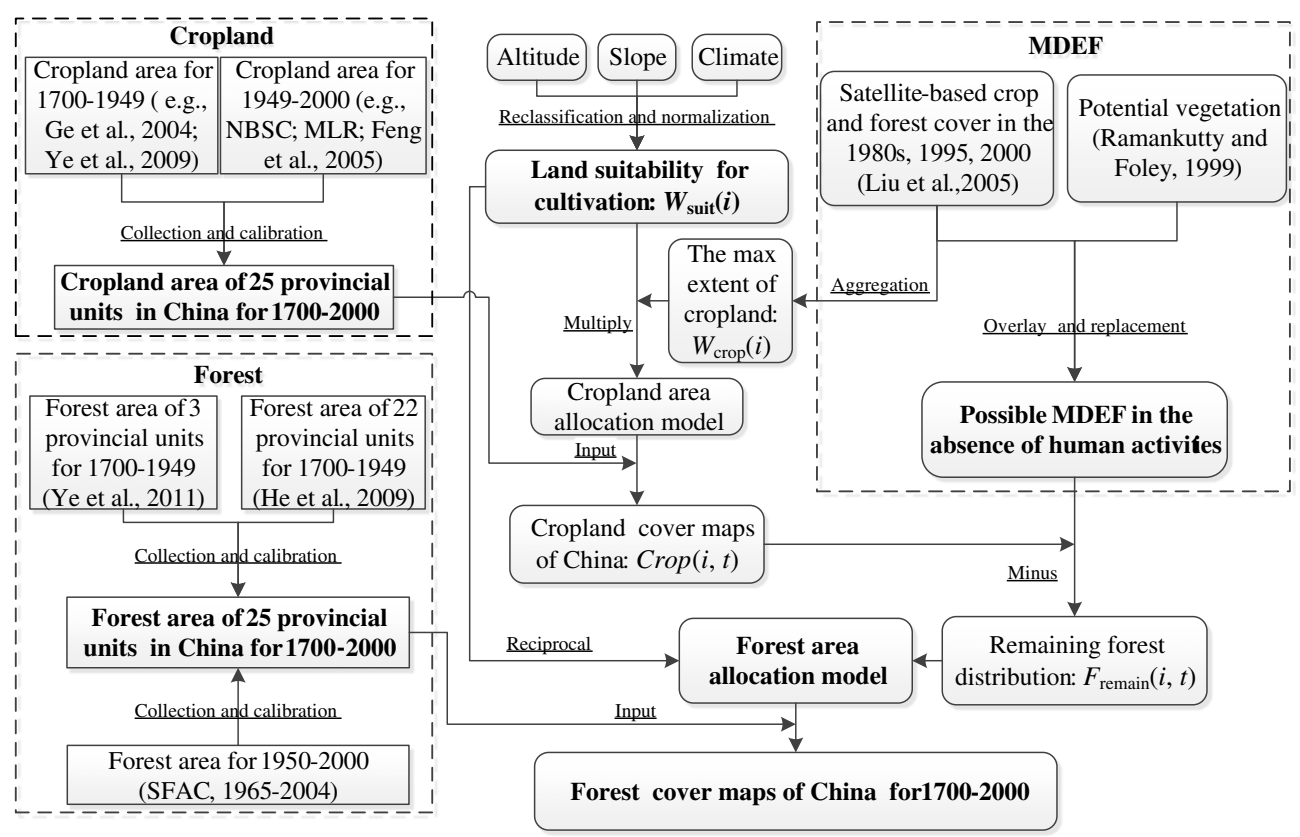

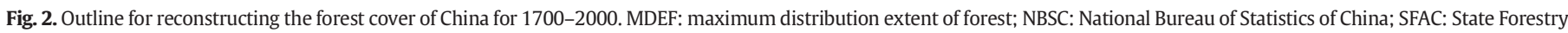
Administration of China.

study, three quantitative factors, i.e., altitude, surface slope, and potential maximum productivity of climate, were used to create the LSC assessment model.

Based on the standards (Table 3), we reclassified and reassigned the altitude and surface slope values. The following equations were used in province $k_{n}(\mathrm{n}=1,2, \ldots, 25)$ to quantify the relationship between altitude, surface slope, and climate and LSC, respectively.

$D^{\prime}\left(k_{n}, i\right)=\frac{\operatorname{Max}\left(D\left(k_{n}, i\right)\right)-D\left(k_{n}, i\right)}{\operatorname{Max}\left(D\left(k_{n}, i\right)\right)}$

$S^{\prime}\left(k_{n}, i\right)=\frac{\operatorname{Max}\left(S\left(k_{n}, i\right)\right)-S\left(k_{n}, i\right)}{\operatorname{Max}\left(S\left(k_{n}, i\right)\right)}$

$C^{\prime}\left(k_{n}, i\right)=\frac{C\left(k_{n}, i\right)}{\operatorname{Max}\left(C\left(k_{n}, i\right)\right)}$

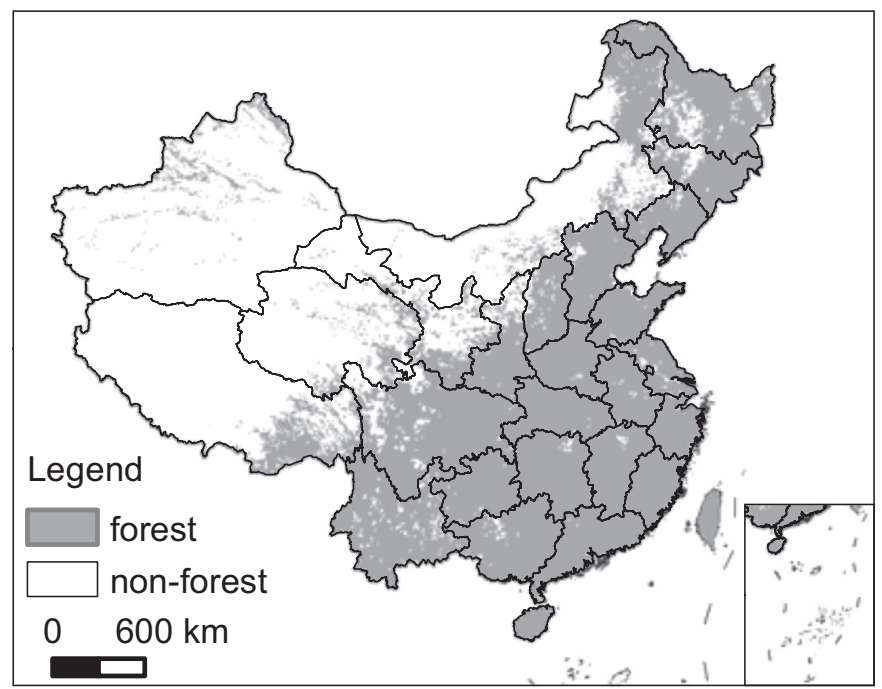

Fig. 3. Possible maximum distribution extent of forest in the absence of human activities. where $D^{\prime}\left(k_{n}, i\right), S^{\prime}\left(k_{n}, i\right)$, and $C^{\prime}\left(k_{n}, i\right)$ are the altitude weight, surface slope weight, and climate weight on LSC of grid cell $i$ in province $k_{n}$; $D\left(k_{n}, i\right), S\left(k_{n}, i\right)$, and $C\left(k_{n}, i\right)$ are the altitude, surface slope, and climatic potential productivity value of grid cell $i$ in province $k_{n}$; $\operatorname{Max}\left(D\left(k_{n}, i\right)\right)$, $\operatorname{Max}\left(S\left(k_{n}, i\right)\right)$, and $\operatorname{Max}\left(C\left(k_{n}, i\right)\right)$ are the maximum altitude, surface slope, and climatic potential productivity value of grid cell $i$ in province $k_{n}$. Also, the altitude data were cited from the current $1 \mathrm{~km}$ GTOPO30 data set (available at http://eros.usgs.gov/\#/Find_Data/Products_and_ Data_Available/ Elevation_Products). The original slope was calculated using the GTOPO30 data set. The potential maximum productivity of the climate used by this study was the climatology condition (the mean of 1951-1980) from the Data Sharing Infrastructure of Earth System Science (available at http://www.geodata.cn).

The above three normalized factors were multiplied together to calculate LSC.

$W_{\text {suit }}\left(k_{n}, i\right)=D^{\prime}\left(k_{n}, i\right) \cdot S^{\prime}\left(k_{n}, i\right) \cdot C^{\prime}\left(k_{n}, i\right)$

where $W_{\text {suit }}\left(k_{n}, i\right)$ is the LSC value of grid $i$ in province $k_{n}$.

\subsubsection{Cropland area allocation model}

The provincial cropland area was allocated within the present cropland scope according to the spatial weight of the cropland for each grid with a cell size of $10 \mathrm{~km}$. As the cropland was characterized by expansion in the past several centuries, almost all historical cropland was located within the present cropland scope. In this study, we used satellite-based cropland data from the early 1980s to denote the present cropland scope, as the cropland area reached a maximum in the early 1980s for the second half of the 20th century (Feng et al., 2005). In

Table 2

Alpine timberline value of some provincial units in west China (Wang et al., 2004).

\begin{tabular}{lll}
\hline Provincial units name & Provincial units code & Alpine timberline $(\mathrm{m})$ \\
\hline Chuan-Yu & 18 & 4100 \\
Yunnan & 20 & 4100 \\
Tibet & 21 & 4400 \\
Gan-Ning & 23 & 3400 \\
Qinghai & 24 & 4000 \\
Xinjiang & 25 & 3200 \\
\hline
\end{tabular}


Table 3

Reclassification and reassignment of the altitude and surface slope derived from Sun and Shi (2003).

\begin{tabular}{lclc}
\hline Altitude level $(\mathrm{m})$ & Reassigned value $(\mathrm{m})$ & Slope level $\left({ }^{\circ}\right)$ & Reassigned value $\left(^{\circ}\right)$ \\
\hline$\leq 100$ & 100 & $\leq 2$ & 2 \\
$100-250$ & 250 & $2-6$ & 6 \\
$250-500$ & 500 & $6-15$ & 15 \\
$500-750$ & 750 & $15-25$ & 25 \\
$750-1000$ & 1000 & $>25$ & 45 \\
$1000-1500$ & 1500 & & \\
$1500-2000$ & 2000 & & \\
$2000-3000$ & 3000 & & \\
$>3000$ & 4000 & & \\
\hline
\end{tabular}

detail, through overlaying the $10 \times 10 \mathrm{~km}$ grids at the $1 \mathrm{~km}$ satellitebased cropland data from Liu et al. (2005), we could determine whether there was cropland in the $10 \times 10 \mathrm{~km}$ grids. As a result, we obtained the present Boolean crop cover extent map $W_{\text {crop }}\left(k_{n}, i\right)$ for the grid $i$ in province $k_{n}$. For $W_{\text {crop }}\left(k_{n}, i\right), 1$ indicates that there is cropland in this grid, and 0 indicates no cropland.

Using $W_{\text {crop }}\left(k_{n}, i\right)$ and the LSC value, the cropland area of province $k_{n}$ were allocated into the grids at a size of $10 \mathrm{~km}$. The equation is as follows:

$\operatorname{crop}\left(k_{n}, i, t\right)=\operatorname{area}\left(k_{n}, t\right) \cdot \frac{W_{\text {crop }}\left(k_{n}, i\right) \cdot W_{\text {suit }}\left(k_{n}, i\right)}{\sum_{i}^{k_{n}}\left[W_{\text {crop }}\left(k_{n}, i\right) \cdot W_{\text {suit }}\left(k_{n}, i\right)\right]}$

where $\operatorname{crop}\left(k_{n}, i, t\right)$ is the cropland area of grid $i$ of province $k_{n}$ in year $t$; and $\operatorname{area}\left(k_{n}, t\right)$ is the cropland area of province $k_{n}$ in year $t$.

Few grids at the size of $10 \mathrm{~km}$ are fully filled by cropland. Through analysis of the satellite-based crop cover in the 1980s, we found that the maximum cropland area in a grid with a size of $10 \mathrm{~km}$ is $90 \mathrm{~km}^{2}$. Therefore, during the allocation process, we prescribed that the maximum cropland in a grid would not exceed $90 \mathrm{~km}^{2}$. When we detected the cropland area calculated by Eq. (5), we removed all of the excess and implemented a loop to allocate the area until each grid's value met the prescribed limit of $90 \mathrm{~km}^{2}$.

\subsubsection{Forest area allocation model}

Based on the LSC and the MDEF, the provincial forest area was transformed into $10 \mathrm{~km}$ forest cover maps. The maximum value of forest area in each grid is $100 \mathrm{~km}^{2}\left(10 \mathrm{~km} * 10 \mathrm{~km}=100 \mathrm{~km}^{2}\right)$. Initially, the crop covers derived in Section 2.2.3 were subtracted from the MDEF (Eq. (6)) to ensure that the sum of cropland area and forest area in one grid would not exceed $100 \mathrm{~km}^{2}$.

$F_{\text {remain }}\left(k_{n}, i, t\right)=100 \mathrm{~km}^{2}-\operatorname{crop}\left(k_{n}, i, t\right)$

where $F_{\text {remain }}\left(k_{n}, i, t\right)$ is the remaining forest area of grid $i$ of province $k_{n}$ in year $t$ after the subtraction of cropland area.

Subsequently, within the remaining forest distribution extent, the provincial forest area was allocated into grids with $10 \mathrm{~km}$ resolution based on the reciprocal of the LSC.

$F_{\text {cover }}\left(k_{n}, i, t\right)=F_{\text {remain }}\left(k_{n}, i, t\right)-\frac{W_{\text {suit }}\left(k_{n}, i\right)}{\sum_{i}^{k_{n}} W_{\text {suit }}\left(k_{n}, i\right)} \cdot\left[\sum_{i}^{k_{n}} F_{\text {remain }}\left(k_{n}, i, t\right)-F_{\text {area }}\left(k_{n}, t\right)\right]$

where $F_{\text {cover }}\left(k_{n}, i, t\right)$ is the forest area of grid $i$ in year $t ; F_{\text {area }}\left(k_{n}, t\right)$ is the provincial forest area of province $k_{n}$ in year $t$.

The above forest allocation process was looped from 1700 to 2000 with 10 year intervals.

\section{Results and uncertainty analysis}

\subsection{Spatial patterns of forest cover}

Fig. 4 illustrates the forest cover of China at $10 \mathrm{~km}$ resolution over the past 300 years with two decade intervals. From the above four subfigures of Fig. 4, we can see that the forest coverage of China decreased slightly for 1700-1760. Over the next 80 years (1760-1840), the forest coverage of the Sichuan Basin, northeast China and the forested regions in south China decreased obviously. The spatial extent of forest shrunk in these regions as well. The increasing population and deforestation for cultivation were the main driving factors. Subsequently, from 1840 to 1920, more deforestation activities occurred in northeast China, the Sichuan Basin and south China. The forest coverage decreased much in these regions, and the forested regions also shrunk during this period. Starting in the last half of the 19th century, China suffered a series of natural disasters. A large amount of the Han Chinese population from the Shandong Peninsula and Jing-Jin-Ji migrated into northeast China to deforest, which was called Chuang Guandong. In addition, war was another factor leading to deforestation. For example, the Taiping Heavenly Kingdom Rebellion, which started in 1850 and ended in 1873 , spread to 18 provinces (particularly the provinces located in southeast China). And its destruction of forests was extremely serious. In 1920, forested regions only included the surrounding areas of the Sichuan Basin, the west Sichuan plateau, the southeast hilly regions and the northeast mountain regions.

Continuing the trend of the last stage, the forest coverage of China continued decreasing, especially in the surrounding areas of the Sichuan Basin and the Tibet Plateau. In addition, the spatial distribution extent of forest shrunk obviously. In the 1960s, the forest coverage of China was less than $10 \%$, which is the minimum value over the entire study period. Forests could only be found in the northeast mountain regions, the Qinling Mountains and hilly regions of south China.

After the 1960s, particularly after the 1980s, the forest recovered and the forest coverage of many regions increased gradually. The regrowth occurred mainly in the northeast mountainous regions, the southeast forested regions, the west Sichuan plateau, and the southeast Tibet regions where the natural environments are harsh (e.g., the slope value is greater than $25^{\circ}$ and altitude value is greater than $3000 \mathrm{~m}$ ).

In addition, the net changes of forest cover for 1700-1800, 1800$1900,1900-1960$ s and 1960 s-2000 were calculated by the latter (1800, 1900 , the 1960 s and 2000 , respectively) minus the former $(1700,1800$, 1900 and the 1960s, respectively. Fig. 5). According to the characteristics of the net changes illustrated above, two stages can be identified over the past three centuries: the continuous decreasing stage from 1700 to the 1960s (Fig. 5a-c) and the rapid recovery stage from the 1960s to 2000 (Fig. 5d). From 1700 to the 1960s, the deforestation activities occurred mainly in southwest China, especially in the Sichuan Basin and its surrounding areas, hilly regions of south China, the southeast of Gansu province, northeast China and some locations in Xinjiang and the Tibet Plateau. From the 1960s to 2000, the reforestation activities occurred in many traditional forested regions of China, especially in the Tibet Plateau, hilly regions of south China and the Greater Khingan Mountains in Inner Mongolia.

\subsection{Uncertainty analysis}

Because of the absence of historical land cover maps, it is difficult to validate our reconstruction directly. In this study, we tried to analyze the uncertainties of our reconstruction quantitatively via two comparisons, including comparison with satellite-based data and comparison with historical documents-based reconstruction at county scale.

\subsubsection{Comparison with satellite-based data}

The forest cover for 2000 was reconstructed by our model, and the provincial forest area was aggregated from satellite-based forest cover 

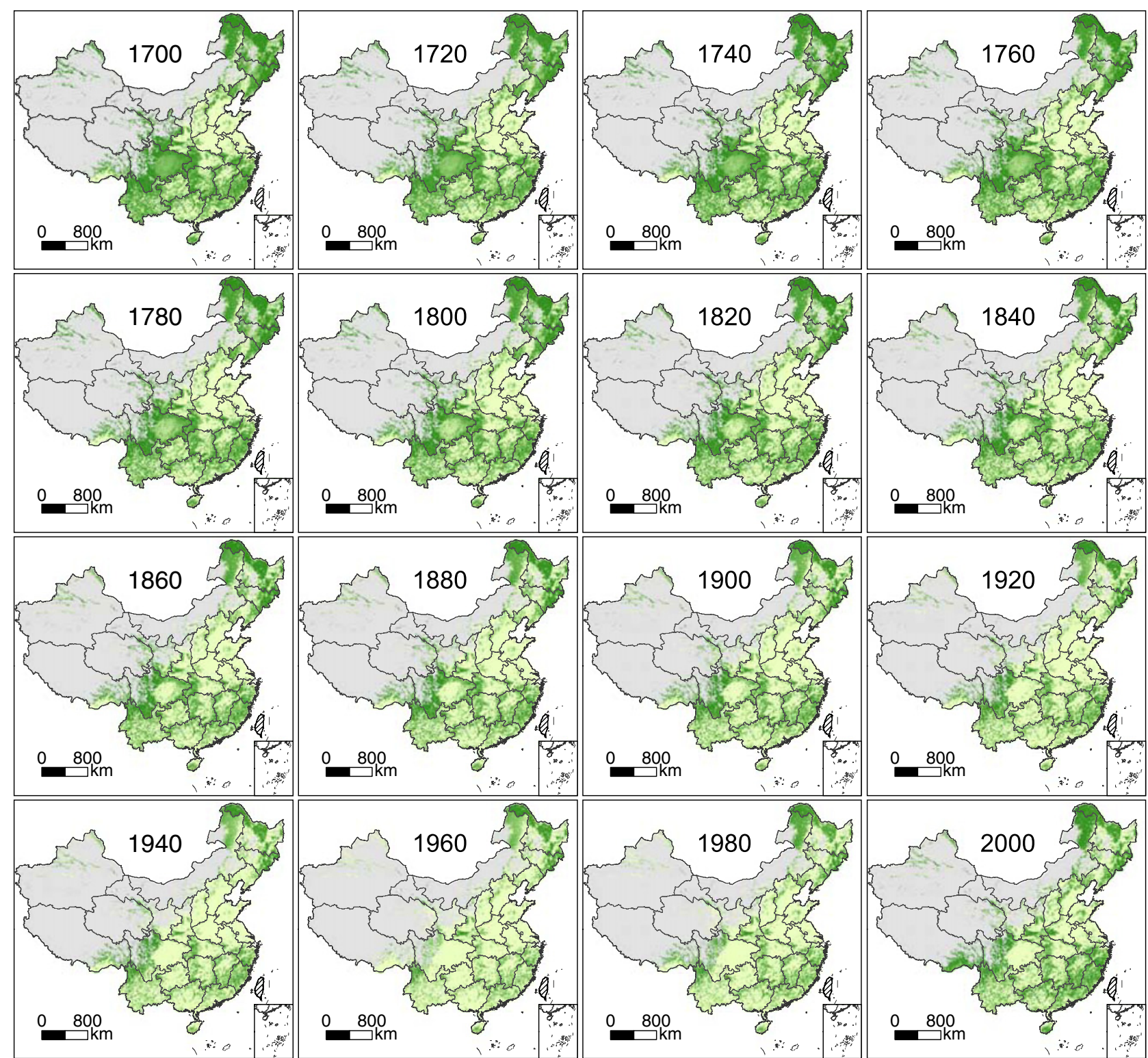

Forest coverage (\%)

$\begin{array}{lllllllllll}0 & 10 & 20 & 30 & 40 & 50 & 60 & 70 & 80 & 90 & 100\end{array}$

Fig. 4. Forest cover in China for $1700-2000$ at $10 \mathrm{~km}$ resolution.
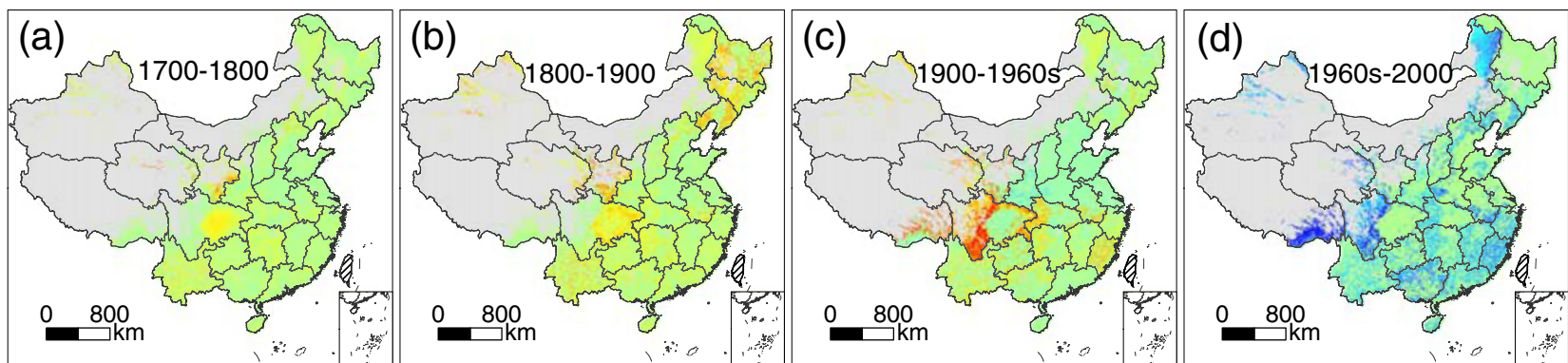

Forest coverage (\%)

$$
\begin{array}{lllllllllll}
-100 & -80 & -60 & -40 & -20 & 0 & 20 & 40 & 60 & 80 & 100
\end{array}
$$

Non-forest UIllA Missing data

Fig. 5. Net changes of forest cover in China for 1700-2000. 


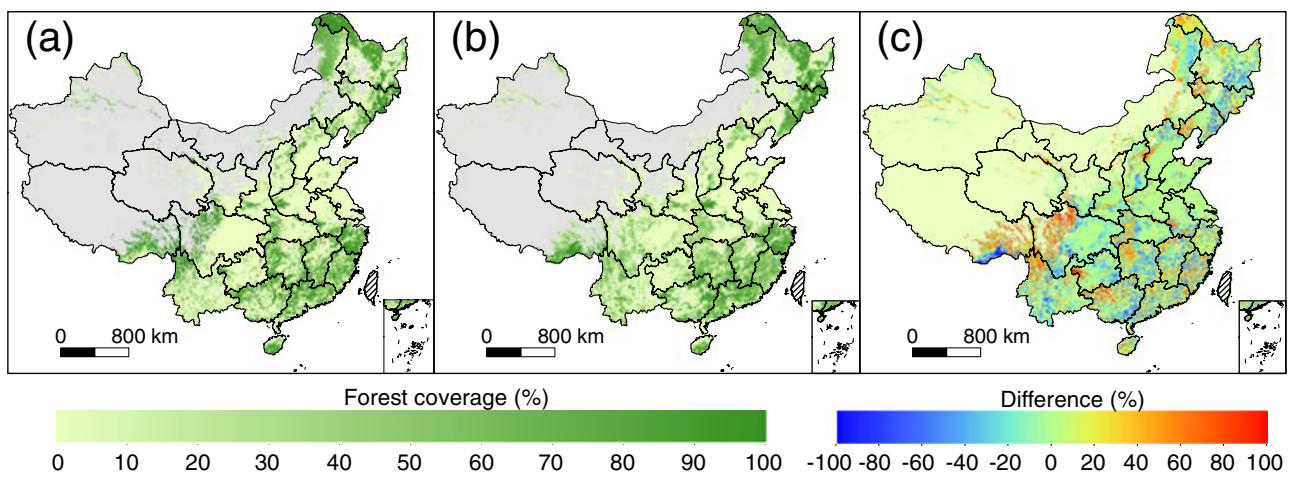

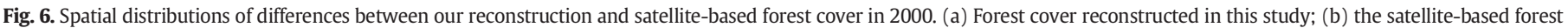
cover; (c) differences between a and b, which were calculated by equation: (a)-(b).

in 2000 to ensure they are the same as the satellite-based data. Then, we compared our reconstruction with satellite-based forest cover for 2000 (Fig. 6).

The spatial patterns of our reconstruction (Fig. 6a) are close with the satellite-based data (Fig. 6b). Both of them show that the main forested regions are the northeast, southeast and southwest of China. The grids whose differences are $-24 \%-25 \%$ account for $66.07 \%$, and the proportion of grids whose differences are larger than $50 \%(>50 \%$ or $<-50 \%)$ is $14.31 \%$ (Table 4 ). In addition, the larger the differences, the lower the proportion of the grid numbers (Table 4 ).

It can be seen from Fig. $6 c$ that the positive differences of our reconstruction are mainly distributed in the west Sichuan plateau, the east of Tibet, and the Hengduan mountainous region of Yunnan province. There are $25.51 \%$ grids whose positive differences are relatively small and range from $1 \%$ to $25 \%$ (Table 4 ). The negative differences of our reconstruction are mainly distributed in southeast Tibet, the surrounding areas of the Sichuan Basin, the southwest of Yunnan province, the north of the Changbai Mountains and some scattered regions in south China. There are $40.56 \%$ grids whose negative differences are relatively small and range from $-24 \%$ to 0 (Table 4 ).

\subsubsection{Comparison with historical documents-based reconstruction}

Ye and Fang (2011) reconstructed the county level forest cover of northeast China for 1683, 1780, 1950 and 2000 based on historical documents. As a case study, the county level forest cover data for 1780 was selected to compare with our reconstruction to assess the accuracy of our reconstruction at county level. The comparison results are illustrated in Fig. 7.

Generally, our reconstruction (Fig. 7a) and the data of Ye and Fang (2011) (Fig. 7b) are close. Both show that the forest is mainly distributed in the Lesser Khingan Mountains and Changbai Mountains regions, and the differences of these regions are at most $-9 \%-10 \%,-29 \%$ to $-10 \%$ and $11 \%-30 \%$ (Fig. 7c). The number of counties whose relative difference range from $-29 \%$ to $30 \%$ is 99 , accounting for $74.44 \%$ of all the counties, whereas the number of counties whose relative difference is greater than $50 \%$ ( $>50 \%$ or $<-50 \%$ ) is 20 , only accounting for $15.04 \%$ of all the counties (Table 5 ).

The negative differences of most counties are distributed in hilly areas in the western Liaoning Province and Songhua River valley, and the difference values of most counties range from $-29 \%$ to $-10 \%$. In terms of positive differences, the distribution scope is smaller than the negative one, and most of them are distributed in hilly areas in the eastern Liaoning Province and Sanjiang Plains. The positive differences of most counties range from $11 \%$ to $30 \%$ and $>50 \%$ (Table 5 ).

\section{Discussion and conclusions}

\subsection{Discussion}

Based on the understanding of the forest change history of China and some rational assumptions, we devised the LSC assessment model and provincial forest area allocation model. Through these models, the provincial forest area data set was allocated into spatially explicit grid cells with the size of $10 \mathrm{~km}$. Some uncertainties, however, may exist.

Although the original forest area we used is more accurate than previous studies, there is still room for improvement. For example, in the fifth and sixth forest resources inventory period (1994-2003), the international definition of forest was adopted, and the crown density changed from more than $30 \%$, which is the standard used in the previous four forest resource inventory time periods, to not less than $20 \%$ (SFAC, 1999). Until now, it is difficult to estimate the biases caused because of the change of investigation standards. In addition, as noted in He et al. (2008), the records in historical archives are mainly qualitative descriptions, which are almost impossible to strictly quantify based on current standards, and the forest in his research is generally defined as the woodland that occupied certain areas. Thus, the data of He et al. (2008) captured the change trend of historical forest area of China at the provincial scale, and more historical information concerning the forest area is needed in future studies.

There are several uncertainties related to the approach of deriving the MDEF. Firstly, we overlooked climate change during the past several centuries. The distribution extent of forest and the alpine timberline perhaps will be influenced by climate change. Also, only the main land use types (i.e., the cultivated regions and built-up regions) were replaced by RF99, and perhaps some parts of pastureland that transformed from forest were overlooked.

In the development of the LSC assessment model, the traditional cultivated regions located in the middle and eastern parts of China were our major consideration. Some factors that perhaps affected the LSC in west China were not incorporated into our model. For example, in the traditional cultivated region of China, the rainfall is abundant, and the irrigation systems are advanced, so the distance to rivers is not a main factor affecting the LSC. However, in west China, because of the scarce precipitation, the distance to rivers does affect the development of agriculture, which can also be seen from satellite-based crop cover data in

Table 4

Statistical classifications of differences of our reconstruction with satellite-based forest cover in 2000

\begin{tabular}{|c|c|c|c|c|c|c|c|c|}
\hline Difference level (\%) & -100 to -75 & -74 to -50 & -49 to -25 & $-24-0$ & $1-25$ & $26-50$ & $51-75$ & $76-100$ \\
\hline Proportion of grid number (\%) & 1.01 & 4.27 & 10.47 & 40.56 & 25.51 & 9.15 & 5.98 & 3.05 \\
\hline
\end{tabular}




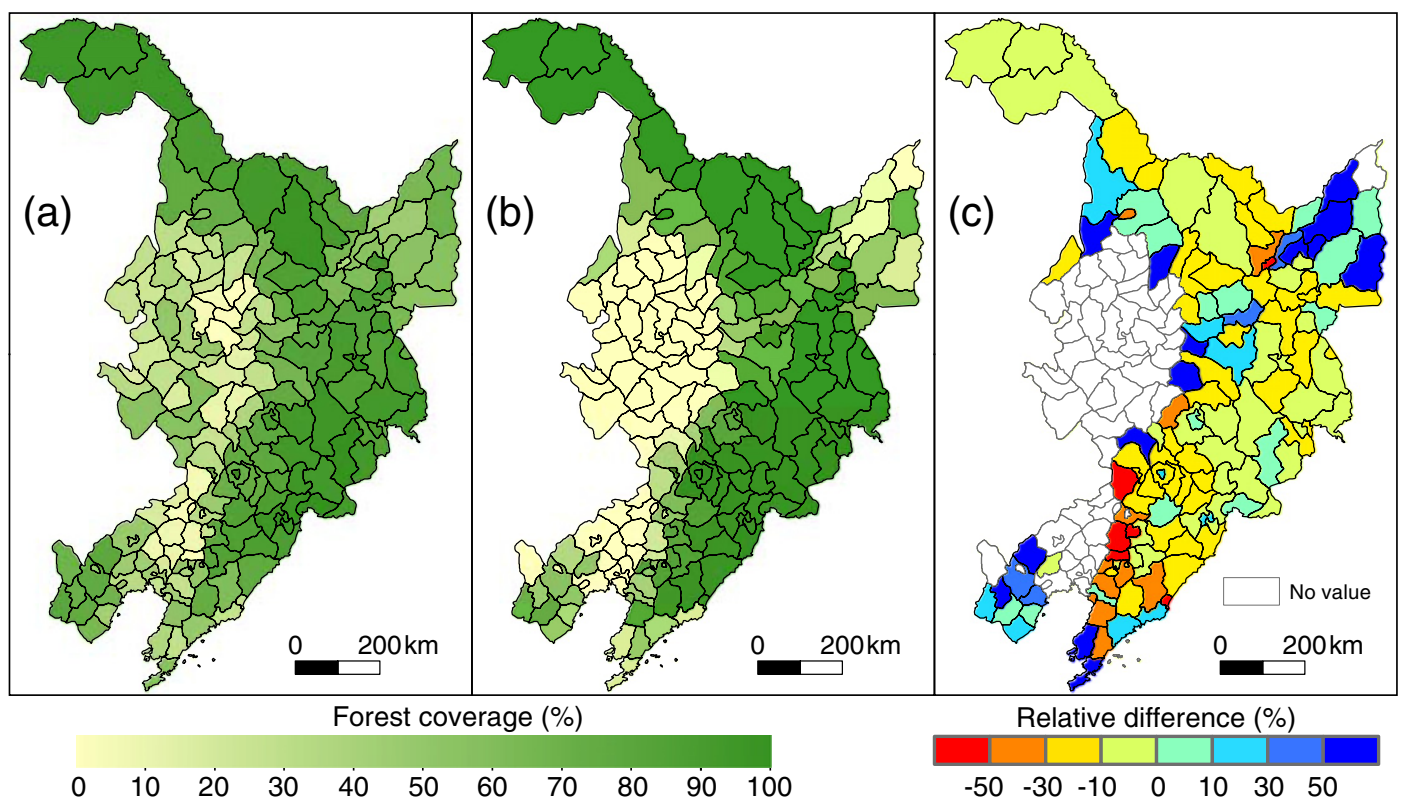

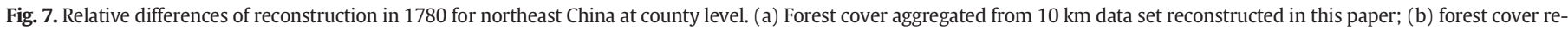
constructed by Ye and Fang (2011); (c) relative difference between a and b, which were calculated by equation [(a) - (b)] / (b) at county level.

the 1980s (Liu et al., 2005). Developing different LSC assessment models for different regions of China in subsequent studies and taking more details at the regional scale into consideration perhaps will improve the accuracy of the forest area allocating spatial weights.

Moreover, population is often used as an important proxy in historical land use and land cover reconstructions (e.g., Pongratz et al., 2008; Kaplan et al., 2009; Klein Goldewijk et al., 2011; Klein Goldewijk and Verburg, 2013). However, the cause-effect relationship between population and changes in land use and land cover is complex and less straightforward when analyzed across longer periods of time. In terms of China, the validity of using this relationship is limited too because many times large-scale population migration changed the spatial patterns of China's population obviously over the past several centuries, including the southward migrations that occurred in the Jin dynasty, in the "An Lushan Rebellion" post period (the late Tang dynasty) and in the Song dynasty (Ge et al., 1993). In the Ming and Qing dynasties, the migration of people from the Hubei and Hunan provinces to the Sichuan province and the "Chuang Guandong" event (i.e., the farmers of the Shandong Peninsula and Jing-Jin-Ji rushed into northeast China) also affected the distribution of the population dramatically. Even in modern times, the population has tended to migrate to east or south coastal areas under the help of the "Reform and Opening up" policy. Therefore, the relationship between population and changes in land use and land cover has been altered much over the past 300 years. Using an unchanged relationship from past to present to reconstruct the historical forest cover of China will lead to increased uncertainties.

\subsection{Conclusions}

Within the MDEF, the LSC was assessed, and the provincial forest area allocation model was devised. Through these models, $10 \mathrm{~km}$ forest cover maps of China with 10 year intervals for $1700-2000$ were reconstructed. Our reconstruction accurately reflected the spatial patterns of forest cover of China over the past three centuries. The results indicated that, from 1700 to the 1960s, the deforestation activities mainly occurred in southwest China, especially the Sichuan Basin and its surrounding areas, hilly regions of south China, the southeast of Gansu provinces, northeast China and some areas in Xinjiang and the Tibet Plateau. From the 1960s to 2000, the reforestation activities occurred in many traditional forested regions of China, especially in hilly regions of south China, the Greater Khingan Mountains of Inner Mongolia and the Tibet Plateau.

By comparison with satellite-based forest cover data for 2000 , we found that our reconstruction has good agreement with the satellitebased data. The grids with differences less than $25 \%$ account for as much as $66.07 \%$ of all grids. Also, the proportion of grids whose differences are larger than $50 \%$ is $14.31 \%$. The comparison with the historical documents-based forest cover data indicated that the number of counties whose relative differences range from $-29 \%$ to $30 \%$ is 99 , accounting for $74.44 \%$ of all the counties, whereas the number of counties whose relative difference are larger than $50 \%$ is 20 , only accounting for $15.04 \%$ of all the counties. The spatially explicit forest data set of China over the past 300 years that we created could serve as underlying land use/cover data for impact studies of historical LUCC on global or regional climate change, hydrological cycles, and carbon cycles.

\section{Acknowledgments}

We thank reviewers for their helpful comments and Yu Ye of Beijing Normal University for providing the county level forest area data for northeast China. This research was supported by National Natural Science Foundation of China (Grant No. 41271227 and 41471171) and the China Global Change Research Program (Grant No. 2010CB950901) of the Ministry of Science and Technology of the People's Republic of China.

Table 5

Statistics of the county-level relative differences of our forest reconstruction for 1780 in northeast China.

\begin{tabular}{|c|c|c|c|c|c|c|c|c|}
\hline Relative difference & $<-50$ & -49 to -30 & -29 to -10 & $-9-10$ & $11-30$ & $31-50$ & $>50$ & No value* \\
\hline The number of county & 6 & 10 & 42 & 48 & 9 & 4 & 14 & 51 \\
\hline The percent of the number of county (\%) & 4.51 & 7.52 & 31.58 & 36.09 & 6.77 & 3.01 & 10.53 & - \\
\hline
\end{tabular}

* Because the data of Ye and Fang (2011) is zero, the relative differences of these counties cannot be calculated. 


\section{References}

Bala, G., et al., 2007. Combined climate and carbon-cycle effects of large-scale deforestation. Proc. Natl. Acad. Sci. 104 (16), 6550-6555. http://dx.doi.org/10.1073/pnas. 0608998104.

Bathiany, S., Claussen, M., Brovkin, V., Raddatz, T., Gayler, V., 2010. Combined biogeophysical and biogeochemical effects of large-scale forest cover changes in the MPI earth system model. Biogeosciences 7 (5), 1383-1399. http://dx.doi.org/10. 5194/bg-7-1383-2010.

Bounoua, L., DeFries, R., Collatz, G.J., Sellers, P., Khan, H., 2002. Effects of land cover conversion on surface climate. Clim. Chang. 52 (1-2), 29-64. http://dx.doi.org/10.1023/a: 1013051420309.

Ellis, E.C., et al., 2013. Used planet: a global history. Proc. Natl. Acad. Sci. 110 (20), 7978-7985. http://dx.doi.org/10.1073/pnas.1217241110.

Fan, B.M., Dong, Y., 2001. A discussion on China's ancient forest coverage. J. Beijing For. Univ. 23 (4), 60-65.

Feddema, J.J., et al., 2005. The importance of land-cover change in simulating future climates. Science 310 (5754), 1674-1678. http://dx.doi.org/10.1126/science.1118160.

Feng, Z.M., Liu, B.Q., Yang, Y.Z., 2005. A study of the changing trend of Chinese cultivated land amount and data reconstructing: 1949-2003. J. Nat. Resour. 20 (1), 35-43.

Fuchs, R., Herold, M., Verburg, P.H., Clevers, J.G.P.W., 2013. A high-resolution and harmonized model approach for reconstructing and analysing historic land changes in Europe. Biogeosciences 10 (3), 1543-1559. http://dx.doi.org/10.5194/bg-10-1543-2013.

Fuchs, R., Herold, M., Verburg, P.H., Clevers, J.G.P.W., Eberle, J., 2015. Gross changes in reconstructions of historic land cover/use for Europe between 1900 and 2010. Glob. Chang. Biol. 21 (1), 299-313. http://dx.doi.org/10.1111/gcb.12714.

Ge, J.X., Cao, S.J., Wu, S.D., 1993. History of Chinese Immigrants. Fujian People's Publishing House, Fuzhou, China (304-316 pp.).

Ge, Q.S., et al., 2004. Spatiotemporal dynamics of reclamation and cultivation and its driving factors in parts of China during the last three centuries. Prog. Nat. Sci. 14 (7), 605-613. http://dx.doi.org/10.1080/10020070412331344021.

Ge, Q.S., Dai, J.H., He, F.N., Pan, Y., Wang, M.M., 2008. Land use changes and their relations with carbon cycles over the past 300 a in China. Sci. China Ser. D Earth Sci. 51 (6), 871-884. http://dx.doi.org/10.1007/s11430-008-0046-z.

Han, M.L., 2012. Historical Agricultural Geography of China. Peking University Press, Beijing, China (13-47 pp.).

He, F.N., Ge, Q.S., Dai, J.H., Rao, Y.J., 2008. Forest change of China in recent 300 years J. Geogr. Sci. 18 (1), 59-72. http://dx.doi.org/10.1007/s11442-008-0059-8.

He, F.N., Li, S.C., Zhang, X.Z., Ge, Q.S., Dai, J.H., 2013. Comparisons of cropland area from multiple datasets over the past 300 years in the traditional cultivated region of China. J. Geogr. Sci. 23 (6), 978-990. http://dx.doi.org/10.1007/s11442-013-1057-z.

He, F., et al., 2014. Simulating global and local surface temperature changes due to Holocene anthropogenic land cover change. Geophys. Res. Lett. 41 (2), 623-631. http://dx. doi.org/10.1002/2013gl058085.

Houghton, R.A., Hackler, J.L., 2003. Sources and sinks of carbon from land-use change in China. Glob. Biogeochem. Cycles 17 (2). http://dx.doi.org/10.1029/2002gb001970.

Houghton, R.A., et al., 2012. Carbon emissions from land use and land-cover change. Biogeosciences 9 (12), 5125-5142. http://dx.doi.org/10.5194/bg-9-5125-2012.

Hurtt, G.C., et al., 2006. The underpinnings of land-use history: three centuries of globa gridded land-use transitions, wood-harvest activity, and resulting secondary lands. Glob. Chang. Biol. 12 (7), 1208-1229. http://dx.doi.org/10.1111/j.1365-2486.2006. 01150x

Jetz, W., Wilcove, D.S., Dobson, A.P., 2007. Projected impacts of climate and land-use change on the global diversity of birds. Plos Biol. 5 (6), 1211-1219. http://dx.doi. org/10.1371/journal.pbio.0050157.

Kaplan, J.O., Krumhardt, K.M., Zimmermann, N., 2009. The prehistoric and preindustrial deforestation of Europe. Quat. Sci. Rev. 28 (27-28), 3016-3034. http://dx.doi.org/10. 1016/j.quascirev.2009.09.028.

Kaplan, J.O., et al., 2011. Holocene carbon emissions as a result of anthropogenic land cover change. The Holocene 21 (5), 775-791. http://dx.doi.org/10.1177/0959683610386983.

Klein Goldewijk, K., 2001. Estimating global land use change over the past 300 years: the HYDE database. Glob. Biogeochem. Cycles 15 (2), 417-433. http://dx.doi.org/10. 1029/1999gb001232.

Klein Goldewijk, K., Verburg, P.H., 2013. Uncertainties in global-scale reconstructions of historical land use: an illustration using the HYDE data set. Landsc. Ecol. 28 (5), 861-877. http://dx.doi.org/10.1007/s10980-013-9877-x.

Klein Goldewijk, K., Beusen, A., van Drecht, G., de Vos, M., 2011. The HYDE 3.1 spatially explicit database of human-induced global land-use change over the past 12,000 years. Glob. Ecol. Biogeogr. 20 (1), 73-86. http://dx.doi.org/10.1111/j.1466-8238.2010.00587.x

Leite, C.C., Costa, M.H., Soares-Filho, B.S., Viana Hissa, L.d.B., 2012. Historical land use change and associated carbon emissions in Brazil from 1940 to 1995. Glob. Biogeochem. Cycles 26, GB2011. http://dx.doi.org/10.1029/2011gb004133.

Levavasseur, G., Vrac, M., Roche, D.M., Paillard, D., Guiot, J., 2013. An objective methodology for potential vegetation reconstruction constrained by climate. Glob. Planet. Chang. 104 (2013), 7-22. http://dx.doi.org/10.1016/j.gloplacha.2013.01.008.
Ling, D.X., 1983. Changes of forest resources in China. Agric. Hist. China 2, 26-36.

Liu, M.L., Tian, H.Q., 2010. China's land cover and land use change from 1700 to 2005: estimations from high-resolution satellite data and historical archives. Glob. Biogeochem. Cycles 24, GB3003. http://dx.doi.org/10.1029/2009gb003687.

Liu, J.Y., et al., 2005. Spatial and temporal patterns of China's cropland during 1990-2000: an analysis based on Landsat TM data. Remote Sens. Environ. 98 (4), 442-456. http://dx. doi.org/10.1016/j.rse.2005.08.012.

Liu, J.Y., et al., 2014. Spatiotemporal characteristics, patterns, and causes of land-use changes in China since the late 1980s. J. Geogr. Sci. 24 (2), 195-210. http://dx.doi. org/10.1007/s11442-014-1082-6.

Ma, Z.L., Song, C.S., Zhang, Q.H., 1997. The Change of China Forest, 45. China Forestry Publishing House, Beijing, China (13-28 pp.).

Miao, L.J., et al., 2013. Synthesis of China's land use in the past 300 years. Glob. Planet. Chang. 100 (2013), 224-233. http://dx.doi.org/10.1016/j.gloplacha.2012.10.021.

Ministry of Land and Resources of China (MLR), 1987-1997. Annual Report on Chinese Land Resources. Geological publishing House, Beijing, China.

National Bureau of Statistics of China (NBSC), 1950-1961. Statistical Yearbook of China. China statistical Publisher House, Beijing, China.

National Bureau of Statistics of China (NBSC), 1953. Statistical Yearbook of China. China statistical Publisher House, Beijing, China.

National Bureau of Statistics of China (NBSC), 1997-2001. Statistical Yearbook of China. China statistical Publisher House, Beijing, China.

Pitman, A.J., et al., 2011. Importance of background climate in determining impact of landcover change on regional climate. Nat. Clim. Chang. 1 (9), 472-475. http://dx.doi.org/ 10.1038/nclimate1294.

Pongratz, J., Reick, C., Raddatz, T., Claussen, M., 2008. A reconstruction of global agricultural areas and land cover for the last millennium. Glob. Biogeochem. Cycles 22 (3), GB3018. http://dx.doi.org/10.1029/2007gb003153.

Pongratz, J., Reick, C.H., Raddatz, T., Claussen, M., 2010. Biogeophysical versus biogeochemical climate response to historical anthropogenic land cover change. Geophys. Res. Lett. 37, L08702. http://dx.doi.org/10.1029/2010gl043010.

Qin, D.H., 2005. Climate and Environment Change of China. Science Press, Beijing, China (489-490 pp.).

Ramankutty, N., Foley, J.A., 1999. Estimating historical changes in global land cover: croplands from 1700 to 1992. Glob. Biogeochem. Cycles 13 (4), 997-1027. http://dx.doi. org/10.1029/1999gb900046.

State Forestry Administration of China (SFAC), 1965, 1977, 1982, 1989, 1994, 1999, 2004. Forest Resources Statistics of China for Periods 1950-62, 1973-76, 1977-81, 1984-88, 1989-93, 1994-98 and 1999-2003. China Forestry Press, Beijing, China.

Sterling, S.M., Ducharne, A., Polcher, J., 2013. The impact of global land-cover change on the terrestrial water cycle. Nat. Clim. Chang. 3 (4), 385-390. http://dx.doi.org/10. 1038/nclimate1690.

Sun, H., Shi, Y.L., 2003. China Agricultural Land Use. Jiangsu Science and Technology Publishing House, Nanjing.

Tan, Q.X., 1991. Concise Historical Atlas of China. SinoMaps Press, Beijing, China.

Tian, H., Banger, K., Bo, T., Dadhwal, V.K., 2014. History of land use in India during 1880-2010: large-scale land transformations reconstructed from satellite data and historical archives. Glob. Planet. Chang. 121 (2014), 78-88. http://dx.doi.org/10. 1016/j.gloplacha.2014.07.005.

Vitousek, P.M., Mooney, H.A., Lubchenco, J., Melillo, J.M., 1997. Human domination of Earth's ecosystems. Science 277 (5325), 494-499. http://dx.doi.org/10.1126/science. 277.5325 .494

Wang, X.P., Zhang, L., Fang, J.Y., 2004. Geographical differences in alpine timberline and its climatic interpretation in China. Acta Geograph. Sin. 59 (6), 871-879.

Wu, C.H., 1996. Chinese Agricultural History. Police-Education Press, Beijing, China (1-1295 pp.)

Yang, Y., et al., 2014. A review of historical reconstruction methods of land use/land cover. J. Geogr. Sci. 24 (4), 746-766. http://dx.doi.org/10.1007/s11442-014-1117-z.

Yang X, Jin, X, Guo, B., Long, Y., Zhou, Y., 2015. Research on reconstructing spatial distribution of historical cropland over 300 years in traditional cultivated regions of China. Glob. Planet. Chang. 128, 90-102. http://dx.doi.org/10.1016/j.gloplacha.2015.02.007.

Ye, Y., Fang, X., 2011. Spatial pattern of land cover changes across northeast China over the past 300 years. J. Hist. Geogr. 37 (4), 408-417. http://dx.doi.org/10.1016/j.jhg. 2011.08.018.

Ye, Y., Fang, X.Q., Ren, Y.Y., Zhang, X.Z., Chen, L., 2009. Cropland cover change in northeast China during the past 300 years. Sci. China Ser. D Earth Sci. 52 (8), 1172-1182. http://dx.doi.org/10.1007/s11430-009-0118-8.

Zhang, X.Z., Wang, W.-C., Fang, X.Q., Ye, Y., Zheng, J.Y., 2011. Vegetation of northeast China during the late seventeenth to early twentieth century as revealed by historical documents. Reg. Environ. Chang. 11 (4), 869-882. http://dx.doi.org/10.1007/s10113011-0224-y.

Zhang, X.Z., He, F.N., Li, S.C., 2013. Reconstructed cropland in the mid-eleventh century in the traditional agricultural area of China: implications of comparisons among datasets. Reg. Environ. Chang. 13 (5), 969-977. http://dx.doi.org/10.1007/s10113012-0390-6. 